\title{
The impact of exchange rate on inflation and economic growth in Vietnam
}

\author{
Thanh Tung Hoang ${ }^{a^{*}}$, Van Anh Nguyen Thi a and Hoang Dinh Minh ${ }^{b}$
}

${ }^{a}$ University of Labour and Social Affairs, Vietnam

${ }^{b}$ Academy of Politics Region 1, Vietnam

\begin{tabular}{l}
\hline C H R O N I C L E \\
\hline Article history: \\
Received: October 152019 \\
Received in revised format: No- \\
vember 2 2019 \\
Accepted: November 3, 2019 \\
Available online: \\
November 5, 2019 \\
\hline Keywords: \\
Exchange rate \\
Vector regression model \\
VAR model \\
Growth \\
Inflation \\
Macro factors \\
Macroeconomic
\end{tabular}

\section{A B S T R A C T}

In this article, the research team uses the VAR self-regression vector model to evaluate the impact of exchange rates on inflation and economic growth in Vietnam over the period 2005-2018. With six endogenous variables included in the VAR model: bilateral real exchange rate (Er), money supply (M2), exports (X), imports (IM), GDP at 2010 comparative prices (GDPR), the consumer price index (CPI) and the two exogenous variables, international price ( $\mathrm{Pw}$ ) and US Federal Reserve interest rate (Ifed), the research team examines the impact of exchange rates on endogenous variables in the model and considers the reaction of inflation and economic growth on various shocks. Based on the quantitative results, the research team will recommend some discussions to contribute for the improvement of Vietnam's macro environment, trade balance, inflation control, and economic growth support; implementing the goal of macroeconomic stability to suit the period of international economic integration and improving national competitiveness.

Macroeconomic

\section{Introduction}

During the past few years, there have been several studies concentrated on the relationship between price and supply (Ito \& Sato, 2008; Bodart, 1996; Hung \& Pfau, 2009). Vo (2000) analyzed the relationship between price and supply in Vietnam with 1900: 12 - 1994: 12 data series and concluded that nominal money supply growth, the deviation between the rate of domestic currency devaluation and the high-interest rate should be considered as factors used to predict inflation, while production growth rate could only maintain a short-term impact. Hung and Pfau (2008) used the VAR model with some variables including output, price, money supply, real interest rate, credit in the economy, the exchange rate for their study, the interaction of monetary policy on the economy. The study points to a tight link between the money supply and real output, but there was no strong connection between money supply and prices. The study also showed that the interest rate channel played little role in the transmission of monetary policy, exchange rate channels and credit channels played a stronger role. Lan (2010) used the SVAR model as a variant of the VAR model to analyze the monetary policy shift mechanism for a large open economy such as Vietnam over the period 1998-2009. Some conclusions have been drawn by the authors: Money M2 tend to have positive effects on economic growth. Exchange rate fluctuations depend heavily on monetary policy management through interest rate instruments and money supply. Minh (2009) used the VAR self-regression vector model to experiment with conduction effect. By VAR test model with 6 economic variables: oil price, commodity demand, exchange rate, import price index, consumer price index, and money supply expansion, the authors have come to two remarkable conclusions: (i) the transmission effect of exchange rate is full after about 5-7 months from the exchange rate fluctuation, then gradually decreases; (ii) the transmission effect of exchange rate on consumer prices is greater than the effect on import prices.

\footnotetext{
* Corresponding author.

E-mail address: hoangthanhtung15@gmail.com (T. T. Hoang) 
Huyen (2018) used the VAR model to examine the relationship between exchange rates and output, as well as the relationship between exchange rates and inflation in Vietnam. The authors made some comments from the quantitative results such as the most important component affecting gross domestic product (GDP) growth is itself and price rather than the exchange rate. Increasing exchange rates does not help economic growth and even it may have an opposite effect. Moreover, the exchange rate has a negative impact on the policy of controlling inflation. Trang (2017) used the VAR model and combined with qualitative research to show that: First, the exchange rate has a certain influence on exports, inflation, interest rates and growth. economy; Second, the degree of influence of exchange rates on main export products is not the same and there are conflicting times. The research results show that to achieve the goal of promoting exports without affecting other macroeconomic targets, the exchange rate policy needs to be more complete and able to reconcile the goals in a specific period. Tung and Van Anh (2018) used the VAR model to examine the impact of changes in money supply on growth and inflation through channels of interest, credit and exchange rates. In which, granger test, reaction function, variance decomposition also showed that there are certain effects from monetary policy to output variables, prices in the economy through the exchange rate channel. The study also pointed out that exchange rate stability, reducing dollarization is one of the goals that need to be considered to achieve the goal of stabilizing the macroeconomy of Vietnam.

\section{The transmission mechanism of the impact of exchange rates on inflation and economic growth}

The exchange rate indirectly affects inflation mainly through net import and export, the balance of payments and the price of imported goods (Nguyen, 2011). In addition, exchange rate indirectly affects economic growth through capital, monetary and aggregate demand channels. The impact transmission channels of exchange rate on growth and inflation can be generalized according to Fig. 1 below:

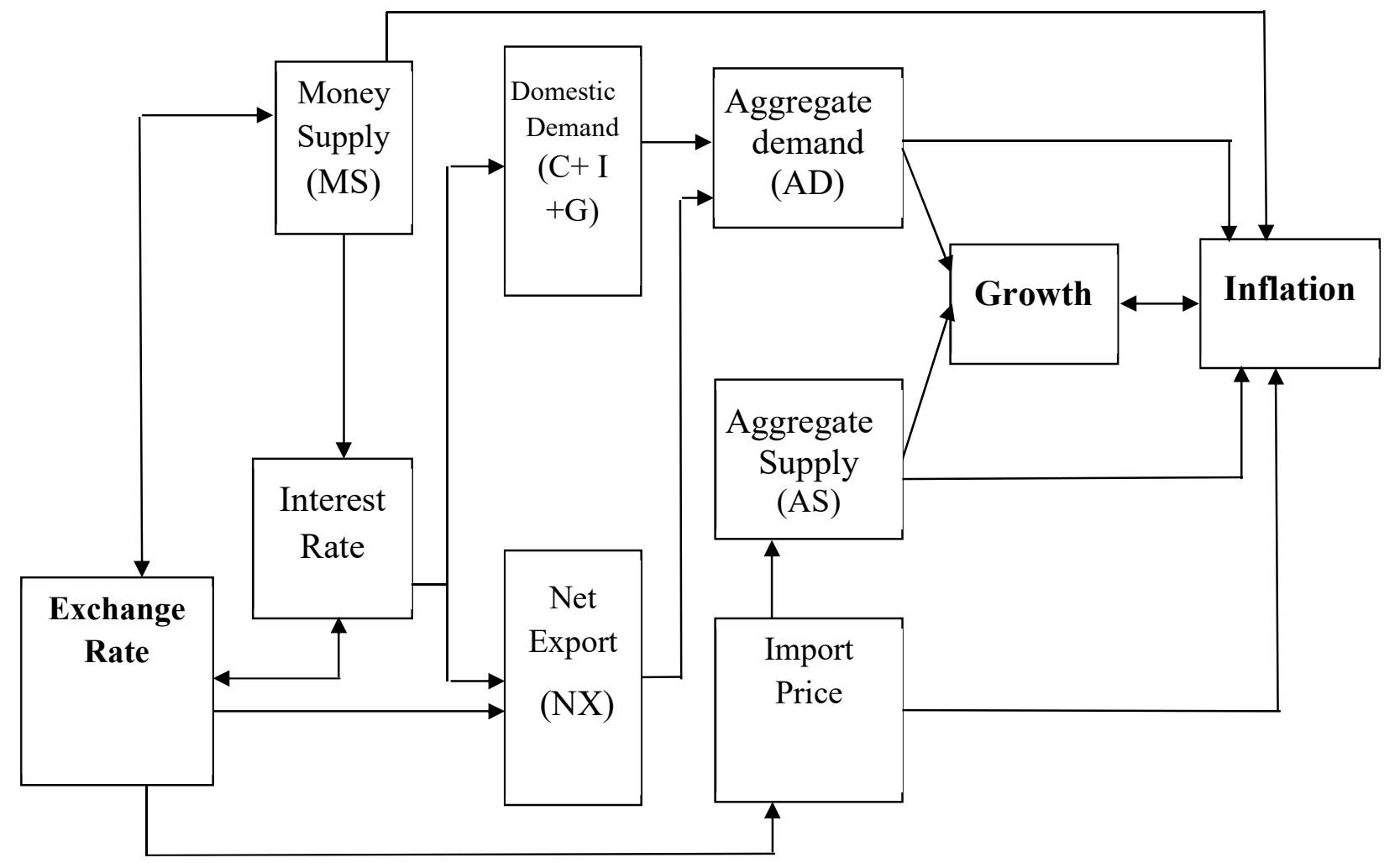

Fig. 1. The impact transmission mechanism of exchange rate on growth and inflation Source: summary of the research team

\subsection{The impact of exchange rates on inflation}

According to Fig. 1, there are 3 transmission channels the impact of exchange rates on inflation:

- The impact transmission mechanism of the exchange rate on inflation through net export: when the domestic currency depreciates against the foreign currency (E rising) ${ }^{1}$, the export turnover increases while the import value decreases, which is a contributor to net export (NX) rise and the trade balance may be improved. Because imports are a component of aggregate

${ }^{1}$ The exchange rate (E) mentioned in this article based on direct quotation method, taking foreign currencies against domestic currencies. 
demand (AD), the increase in $\mathrm{AD}$ will cause the $\mathrm{AD}$ line to shift to the right (in the $\mathrm{AD}-\mathrm{AS}$ model), lead to an increase in inflation.

- The impact transmission mechanism of the exchange rate on inflation through the balance of payment: When the exchange rate increases, net exports increase, improving the trade balance; the IS curve moves to the right (in the IS-LM model), which causes the domestic interest rate rising. In the short term, the increase of foreign currency inflows into the domestic market leads to an improvement in the overall balance of payments. There are two possibilities which could happen:

+ The Central Bank has to supply an additional amount of domestic currency (MS increases) to absorb all the inflowing in foreign currency to keep the exchange rate stable. The rising in money supply put the pressure to increase in inflation;

+ In case the Central Bank is not for the purpose of keeping the local currency stable, there is still an increasing amount of foreign currency in the economy. For high dollarized economies, the total means of payment of the economy still increases (total means of payment is equal to the total of domestic payment instruments and the total means of foreign currency payment) and it creates pressure on prices and pushing up inflation.

- The impacts of exchange rates on inflation through import goods channel: Imported goods can be inputs for domestic production or consumer goods. If it is imported for domestic production, when the exchange rate increases leading to the increase in the cost of inputs, the aggregate supply (AS) line moves upwards to the left, causing inflationary pressures. For imported consumer goods, the going up in the exchange rate makes the price of imported goods in local currency increase, thereby raising the overall price of consumer goods, causing inflation pressure.

\subsection{The impact of exchange rate on growth}

With the continuous change, the exchange rate has an important influence on growth and vice versa the happenings of the economy (recession or economic growth) also have the effect of causing exchange rate fluctuations. Fig. 1 also showed that exchange rate affect growth through two transmission channels: (i) changes in exchange rates affect changes in aggregate demand, which affects economic growth; (ii) changes in exchange rates will affect monetary factors (interest rates, money supply) thereby affecting economic growth. In addition, the impact of exchange rates on economic growth can affect through the aggregate supply channel. Because of the changes in the exchange rate can lead to a change in capital sources which affect technology science and labor productivity. But within the scope of the article, the research team will focus on researching channels affecting aggregate demand, thereby affecting economic growth. Besides, the transmission channel of the exchange rate's impact on economic growth is also affected by some factors such as:

(i) Exchange rate mechanism, there are many studies on the relationship between exchange rate mechanism and economic growth but there is no clear answer as to which exchange rate mechanism is the most suitable for economic growth.

(ii) Foreign direct investment (FDI), devaluation of the local currency will increase the assets of foreign investors compared to domestic investors, leading to an increase in FDI and economic growth.

(iii) International trade, exchange rates impact on international trade through the profits of companies involved in international trade. According to the traditional view, when the local currency depreciates, domestic goods become more competitive in the world market, increased exports bring more profits to domestic enterprises, lead to an increase in capital in short term as well as rising in medium-term investment.

\section{Applying VAR model to test the impact of exchange rates on inflation and economic growth in Vietnam}

\subsection{VAR model and variables in the model}

Based on the effect of transmission mechanism of exchange rate on growth and inflation, and empirical studies on the impact of exchange rate on growth and inflation in Vietnam, the research team have decided to choose and apply vector econometric model (VAR - Vector Autoregression) to test the impact of exchange rates on growth and inflation. The general k-type VAR model has the following form:

In which:

$$
Y_{t}=A_{1} Y_{t-1}+A_{2} Y_{t-2}+\ldots+A_{k} Y_{t-k}+s_{t}+\varepsilon_{t}
$$

$+\mathrm{A}_{\mathrm{i}}$ is the square matrix $\mathrm{m}, \mathrm{i}=1,2,3, \ldots \mathrm{k}$;

$+\mathrm{st}=(\mathrm{s} 1 \mathrm{t}, \mathrm{s} 2 \mathrm{t}, \mathrm{s} 3 \mathrm{t}, \ldots, \mathrm{smt})$;

$+\mathrm{Y}$ includes random variable $\mathrm{m}$;

$+\mathcal{E}_{\mathrm{t}}$ is a white noise vector;

$+\mathrm{S}_{\mathrm{t}}$ vector determines elements, which may include constants, linear, or polynomial trends

The VAR model used in this study is an 8-variable model. There are 6 endogenous variables: Bilateral Real Exchange Rate (Er); Money supply $\left(\mathrm{M}_{2}\right)$; Export (X); Import (IM); Consumer price index (CPI); GDP at constant 2010 prices (GDP ${ }_{\mathrm{R}}$ ); In addition, the author added in the model of international price index variable $(\mathrm{Pw})$ and FED interest rate variable (Ifed) as exogenous variable. (Table 1) 
Table 1

Variables in the VAR model

\begin{tabular}{cclc}
\hline No. & Symbol & & Variable name \\
\hline 1 & CPI & Consumer price index & TCTK, IFS \\
2 & GDP $_{\mathrm{R}}$ & GDP at constant 2010 prices & TCTK \\
3 & $\mathrm{M}_{2}$ & Money supply & IFS, NHNN \\
4 & $\mathrm{X}$ & Export & IFS, TCTK \\
5 & $\mathrm{IM}$ & Import & IFS, TCTK \\
6 & $\mathrm{Er}$ & Bilateral Real Exchange Rate & IFS, NHNN \\
7 & $\mathrm{PW}$ & international price index & IFS \\
8 & $\mathrm{Ifed}$ & FED interest rate & IFS \\
\hline
\end{tabular}

In Table 1, the consumer price index (CPI) variable represents the inflation target, while the gross domestic product at constant 2010 prices $\left(G P_{R}\right)$ represents the income or output index of the economy. At the same time, the GDPR variable has been seasonally adjusted to the moving average method, to ensure shocks reflect changes compared to the long-term trend of that variable. The Ifed variables of Quarter 3, Quarter 4, 2017 and Quarter 1, Quarter 2, Quarter 3 of 2018 have been averaged by the authors based on data of the IMF country Report No.18/207 (International Monetary Fund, 2018). The bilateral real exchange rate is calculated from the bilateral nominal exchange rate data, compiled from IFS and GSO by the research team. The variables CPI, GDP ${ }_{\mathrm{R}}, \mathrm{M}_{2}, \mathrm{X}$, IM, Er, PW, Ifed, after being logarited, are denoted LCPI, LGDP, LM 2 , LX, LIM, LER, LPW, LIFED and variance of data series after being logarited, are denoted as DLCPI, DLGDP, DLM 2 , DLX, DLIM, DLER, DLPW, DLIFED. Based on this model structure, the research team considered the impact of exchange rates on the remaining endogenous variables in the model and also the reaction of inflation and economic growth to various shocks.

\subsection{Checking the stability of the data series}

Before carrying out specific analysis steps, the authors undertook a check on the stability of the data series (including 52 observations, being collected from quarter 1, 2005 to quarter 3, 2018)

\subsubsection{Determine the stopping behavior of the variables included in the model}

To test the stationarity of the variables after the logarithmic, the research team performed unit tests and the results are shown in Table 2

Table 2

Verification of stopping of variables by ADF testing

\begin{tabular}{|c|c|c|c|c|}
\hline \multirow{2}{*}{ Variables } & \multirow{2}{*}{$\mathrm{ADF}$} & \multicolumn{3}{|c|}{ Test critical values: } \\
\hline & & $1 \%$ level & $5 \%$ level & $10 \%$ level \\
\hline LGDP & -2.65634 & -4.14847 & -3.5005 & -3.17962 \\
\hline DLGDP & -8.74385 & -3.56831 & -2.92118 & -2.59855 \\
\hline LCPI & -0.12478 & -4.13728 & -3.4953 & -3.17662 \\
\hline DLCPI & -5.18327 & -3.56002 & -2.91765 & -2.59669 \\
\hline LM2 & -1.48376 & -4.13728 & -3.4953 & -3.17662 \\
\hline DLM2 & -5.06013 & -3.56002 & -2.91765 & -2.59669 \\
\hline LX & -3.99149 & -4.13728 & -3.4953 & -3.17662 \\
\hline DLX & -8.69411 & -3.56002 & -2.91765 & -2.59669 \\
\hline LIM & -4.09656 & -4.13728 & -3.4953 & -3.17662 \\
\hline DLIM & -8.8709 & -3.56002 & -2.91765 & -2.59669 \\
\hline LER & -0.95379 & -4.13728 & -3.4953 & -3.17662 \\
\hline DLER & -4.96058 & -3.56002 & -2.91765 & -2.59669 \\
\hline LPW & -2.15023 & -4.13728 & -3.4953 & -3.17662 \\
\hline DLPW & -4.41165 & -3.56002 & -2.91765 & -2.59669 \\
\hline LIFED & -0.41511 & -4.13728 & -3.4953 & -3.17662 \\
\hline DLIFED & -6.87565 & -3.56002 & -2.91765 & -2.59669 \\
\hline
\end{tabular}

The results in Table 2 show that the discrepancies of DLCPI, DLGDP, DLM 2 , DLX, DLIM, DLER, DLPW, DLIFED chains all stop at the $1 \%$ significance level $(5 \%, 10 \%)$. With the results of the calculation of stationarity as above in the VAR model, all variables will be taken in the first-order differential. The data series in this study is quarterly data, from the first quarter of 2005 to the third quarter of 2018 with all 55 observations, but due to running after the variables latency and taking the difference of variables, the number remaining observation for running VAR model is 48 .

\subsubsection{Determine optimal latency}

To determine the variables included in the VAR model, it is important to assess the optimal latency. After running the VAR and using the verification to determine the optimal number of latency periods, according to the statistical standards LR, FPE, AIC, SC, HQ the optimal delay is 3 (Table 3). 
Table 3

Defining latency in the model

\begin{tabular}{|c|c|c|c|c|c|c|}
\hline Lag & $\log L$ & LR & FPE & AIC & $\mathrm{SC}$ & HQ \\
\hline 0 & 686.1449 & NA & $3.27 e-20$ & -27.83937 & $-27.13767 *$ & -27.57420 \\
\hline 1 & 749.0739 & 102.2596 & $1.09 \mathrm{e}-20$ & -28.96141 & -26.85631 & -28.16589 \\
\hline 2 & 804.7550 & 76.56151 & $5.34 \mathrm{e}-21$ & -29.78146 & -26.27296 & -28.45559 \\
\hline 3 & 859.5327 & $61.62492 *$ & $3.14 \mathrm{e}-21 *$ & $-30.56386^{*}$ & -25.65196 & $-28.70765^{*}$ \\
\hline
\end{tabular}

\subsection{Granger causality test, chain correlation test, and model stability}

Source: VAR model results

\section{(1). Granger causality test}

According to the results of Granger causality test (Table 4), with a 5\% significance level: Money supply has a causal relationship with CPI; CPI has a causal relationship with imports; The interest rate of the Fed is related to the CPI and the CPI has a causal relationship with the interest of the Fed; Exports have a causal relationship with GDP and GDP has a causal relationship with exports. Imports have a causal relationship with GDP and GDP has a causal relationship with imports; International prices have a causal relationship to GDP; Fed interest rate is correlated with GDP; The exchange rate is related to money supply; Exchange rates have a relationship with imports; The exchange rate is related to international prices; The interest rate of the Fed is related to the exchange rate and the exchange rate is related to the Fed interest rate. Money supply has a relationship with imports; Export has a relationship with imports; International prices have a relationship with exports; Fed interest rates have a relationship with exports; International prices have a relationship with imports; International prices are related to the Fed interest rates. With the significance of $10 \%$, it can be further confirmed: International price is related to money supply; Imports have a relationship with exports.

Table 4

Granger causality test

\begin{tabular}{|c|c|c|c|}
\hline Null Hypothesis: & Obs & F-Statistic & Prob. \\
\hline DLM2 does not Granger Cause DLCPI & 51 & 3.47138 & 0.0239 \\
\hline DLCPI does not Granger Cause DLM2 & & 1.57304 & 0.2094 \\
\hline DLIM does not Granger Cause DLCPI & 51 & 1.81172 & 0.159 \\
\hline DLCPI does not Granger Cause DLIM & & 6.68368 & 0.0008 \\
\hline DLIFED does not Granger Cause DLCPI & 51 & 7.92093 & 0.0002 \\
\hline DLCPI does not Granger Cause DLIFED & & 8.22954 & 0.0002 \\
\hline DLX does not Granger Cause DLGDP & 48 & 7.65638 & 0.0004 \\
\hline DLGDP does not Granger Cause DLX & & 7.38516 & 0.0005 \\
\hline DLIM does not Granger Cause DLGDP & 48 & 6.82013 & 0.0008 \\
\hline DLGDP does not Granger Cause DLIM & & 3.12159 & 0.0362 \\
\hline DLPW does not Granger Cause DLGDP & 48 & 3.00042 & 0.0414 \\
\hline DLGDP does not Granger Cause DLPW & & 0.84486 & 0.4773 \\
\hline DLIFED does not Granger Cause DLGDP & 48 & 4.28419 & 0.0102 \\
\hline DLGDP does not Granger Cause DLIFED & & 1.54511 & 0.2173 \\
\hline DLM2 does not Granger Cause DLER & 51 & 1.86690 & 0.1491 \\
\hline DLER does not Granger Cause DLM2 & & 2.71019 & 0.0565 \\
\hline DLIM does not Granger Cause DLER & 51 & 0.44950 & 0.7189 \\
\hline DLER does not Granger Cause DLIM & & 4.71265 & 0.0061 \\
\hline DLPW does not Granger Cause DLER & 51 & 0.96514 & 0.4177 \\
\hline DLER does not Granger Cause DLPW & & 2.86001 & 0.0476 \\
\hline DLIFED does not Granger Cause DLER & 51 & 6.26384 & 0.0012 \\
\hline DLER does not Granger Cause DLIFED & & 12.4356 & $5.00 \mathrm{E}-06$ \\
\hline DLX does not Granger Cause DLM2 & 51 & 1.89329 & 0.1446 \\
\hline DLM2 does not Granger Cause DLX & & 5.05032 & 0.0043 \\
\hline DLIM does not Granger Cause DLM2 & 51 & 9.77843 & $5.00 \mathrm{E}-05$ \\
\hline DLM2 does not Granger Cause DLIM & & 6.06686 & 0.0015 \\
\hline DLPW does not Granger Cause DLM2 & 51 & 2.33584 & 0.0868 \\
\hline DLM2 does not Granger Cause DLPW & & 1.70598 & 0.1796 \\
\hline DLIM does not Granger Cause DLX & 51 & 2.30153 & 0.0903 \\
\hline DLX does not Granger Cause DLIM & & 3.16309 & 0.0337 \\
\hline DLPW does not Granger Cause DLX & 51 & 4.29652 & 0.0096 \\
\hline DLX does not Granger Cause DLPW & & 1.88004 & 0.1469 \\
\hline DLIFED does not Granger Cause DLX & 51 & 3.11176 & 0.0358 \\
\hline DLX does not Granger Cause DLIFED & & 2.19749 & 0.1018 \\
\hline DLPW does not Granger Cause DLIM & 51 & 7.82571 & 0.0003 \\
\hline DLIM does not Granger Cause DLPW & & 2.68193 & 0.0583 \\
\hline DLIFED does not Granger Cause DLIM & 51 & 3.54940 & 0.0219 \\
\hline DLIM does not Granger Cause DLIFED & & 2.09326 & 0.1148 \\
\hline DLIFED does not Granger Cause DLPW & 51 & 1.11876 & 0.3518 \\
\hline DLPW does not Granger Cause DLIFED & & 7.00803 & 0.0006 \\
\hline
\end{tabular}




\section{(2). Chain correlation test}

The testing results show that the model is not correlated string (Prob values $>0.1$ ) (Table 5)

Table 5

Chain correlation test

\begin{tabular}{|c|c|c|c|c|c|}
\hline Lags & LM-Stat & Prob & Lags & LM-Stat & Prob \\
\hline 1 & 42.63362 & 0.2073 & 6 & 29.95391 & 0.7508 \\
\hline 2 & 32.94496 & 0.6147 & 7 & 37.94112 & 0.3809 \\
\hline 3 & 35.59696 & 0.4876 & 8 & 26.46450 & 0.8772 \\
\hline 4 & 38.45054 & 0.3592 & 9 & 32.02005 & 0.6584 \\
\hline 5 & 37.77378 & 0.3882 & 10 & 25.67774 & 0.8991 \\
\hline
\end{tabular}

\section{(3). Testing the stability of the model}

The VAR model satisfies the steady-state condition because all modules are in the unit circle (the values of modulus less than 1). (Table 6)

Table 6

Testing the stability of the model

\begin{tabular}{cccc}
\hline & & Root & Modulus \\
\hline-0.954248 & 0.954248 & $0.425744+0.543579 \mathrm{i}$ & 0.690461 \\
$0.946979-0.043495 \mathrm{i}$ & 0.947977 & $0.425744-0.543579 \mathrm{i}$ & 0.690461 \\
$0.946979+0.043495 \mathrm{i}$ & 0.947977 & $0.555868-0.136596 \mathrm{i}$ & \\
$0.095901+0.855740 \mathrm{i}$ & 0.861097 & $0.555868+0.136596 \mathrm{i}$ & \\
$0.095901-0.855740 \mathrm{i}$ & 0.861097 & $-0.332654+0.461105 \mathrm{i}$ & 0.572405 \\
$0.027601+0.854748 \mathrm{i}$ & 0.855193 & $-0.332654-0.461105 \mathrm{i}$ & $0.440706+0.290141 \mathrm{i}$ \\
$0.027601-0.854748 \mathrm{i}$ & 0.855193 & $-0.440706-0.290141 \mathrm{i}$ & 0.568574 \\
$-0.393534-0.603970 \mathrm{i}$ & 0.720867 & -0.112703 & 0.527640 \\
$-0.393534+0.603970 \mathrm{i}$ & 0.720867 & \multicolumn{3}{c}{ Source: VAR model results } & 0.112703 \\
\hline
\end{tabular}

Roots of Characteristic Polynomial

Source: VAR model results

Endogenous variables: DLCPI DLGDP DLER DLM2 DLX DLIM

Exogenous variables: C DLPW DLIFED

Lag specification: 13

No root lies outside the unit circle.

VAR satisfies the stability condition.

\subsection{Estimated results of VAR model}

\subsubsection{Estimated results}

After checking the stoppage, determining the optimal latency, and checking the Granger causality, chained correlation, the stability of the model, the authors proceeded to estimate the model (Table 7). VAR model results have shown the relationship between the variables in the model, the influence of the variables in the present and the latency value (3-quarter optimal delay) of the variable itself as well as the remaining variables to the research variable. From the model results, the authors have conducted the reaction function and variance decomposition to show the relationship between the variables in the model.

Table 7

Estimated results of VAR model

\begin{tabular}{|c|c|c|c|c|c|c|}
\hline & DLCPI & DLGDP & DLER & DLM2 & DLX & DLIM \\
\hline DLCPI(-1) & 0.500079 & -0.041522 & -0.087154 & -0.098387 & -0.641981 & -0.520302 \\
\hline DLCPI(-2) & 0.310581 & 0.037387 & -0.369286 & -0.003249 & 3.513277 & 1.386693 \\
\hline DLCPI(-3) & 0.098703 & -0.040352 & 0.115928 & -0.196554 & -1.700157 & -1.006853 \\
\hline $\operatorname{DLGDP}(-1)$ & 0.202143 & -0.383952 & -0.398516 & -1.085561 & -6.897238 & -3.170826 \\
\hline $\operatorname{DLGDP}(-2)$ & -1.169679 & -0.041795 & 0.851538 & 0.264124 & 0.295918 & 6.224447 \\
\hline $\operatorname{DLGDP}(-3)$ & 0.623999 & 0.546385 & -1.665378 & 1.445140 & 7.297518 & 2.883529 \\
\hline DLER(-1) & 0.299128 & -0.030326 & 0.471682 & -0.123685 & -0.372953 & -0.426449 \\
\hline $\operatorname{DLER}(-2)$ & 0.334192 & 0.144720 & -0.730289 & 0.411085 & 4.182920 & 2.919120 \\
\hline $\operatorname{DLER}(-3)$ & -0.283242 & -0.128058 & 0.570128 & -0.589446 & -2.479998 & -0.812839 \\
\hline DLM2(-1) & 0.232811 & 0.011577 & -0.116698 & 0.587105 & -0.576659 & 0.353469 \\
\hline DLM2 $(-2)$ & 0.105414 & -0.013312 & -0.137762 & 0.090350 & 1.198959 & 0.819245 \\
\hline DLM2(-3) & -0.005419 & -0.006976 & 0.120322 & 0.335591 & -0.871182 & -0.301454 \\
\hline $\operatorname{DLX}(-1)$ & -0.103158 & 0.015484 & 0.099787 & 0.170140 & -0.013263 & 0.266644 \\
\hline $\operatorname{DLX}(-2)$ & 0.051205 & 0.030984 & -0.108983 & 0.149575 & -0.199739 & -0.460754 \\
\hline $\operatorname{DLX}(-3)$ & -0.027068 & -0.026724 & 0.087792 & -0.123286 & -0.533042 & -0.464039 \\
\hline DLIM(-1) & 0.039205 & 0.000876 & -0.030948 & -0.220403 & -0.214691 & -0.458203 \\
\hline $\operatorname{DLIM}(-2)$ & 0.018661 & 0.020723 & 0.009989 & 0.018172 & 0.318007 & 0.225816 \\
\hline $\operatorname{DLIM}(-3)$ & 0.025955 & 0.003897 & -0.035415 & 0.016384 & 0.262131 & -0.208140 \\
\hline C & -0.040591 & 0.012730 & 0.045878 & 0.014543 & -0.077500 & -0.173845 \\
\hline DLPW & 3.224322 & 0.013900 & -1.741032 & -2.204902 & 11.69854 & 12.47603 \\
\hline DLIFED & 0.013771 & 0.001904 & -0.010093 & 0.011993 & 0.032602 & -0.028247 \\
\hline
\end{tabular}

Vector Autoregression Estimates

Source: VAR model results

Standard errors in ( ) \& t-statistics in [ ] 


\subsubsection{Reaction function and variance decomposition}

\section{(1). Reaction function}
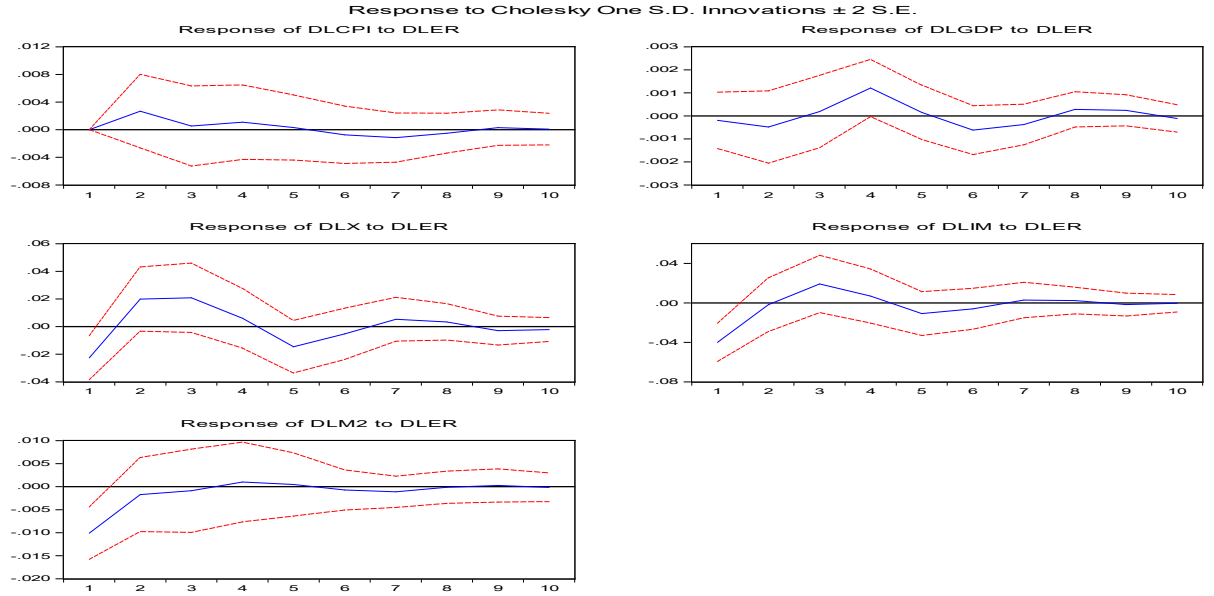

Source: VAR model results

Fig. 2. Impact of exchange rate shock on other endogenous variables

The results of the VAR model estimation and the reaction function (Fig. 2) show that the fluctuation of each variable is in next 10 quarters, assuming the real exchange rate increased by $1 \%$ in the first quarter. The results have shown that:

(i) The increase in exchange rate cause CPI to increase in the first quarter, then drop sharply in the second quarter, slightly increase in the third quarter, then decrease then rose slightly and return to the original values. The exchange rate adjustment will have an immediate impact on inflation in the first quarter;

(ii) When the exchange rate increases, $\mathrm{GDP}_{\mathrm{R}}$ decreases immediately in the first quarter followed by the rising in 2 quarters, then decreases in 2 quarters before slightly increases in the next 2 quarters. The impact of exchange rate on GDPR's fluctuation trend is unclear. There is no firm conclusion on the impact of exchange rates on economic growth;

(iii) If the exchange rate goes up, exports will increase in the first quarter, stabilizes in the second quarter, then decreases in the next two quarters, then increases slightly again;

(iv) Along with increased exports, imports also rise in the first 3 quarters, then reduces in the next 3 quarters, then fluctuates slightly;

(v) The increase in the exchange rate, at first, also leads to a rising in the money supply, but then the money supply remains almost unchanged

\section{(2). Variance decomposition}

In addition to the response function analysis, the variance can be used to assess the importance of different shocks in explaining the variability of inflation and growth. The persistent nature of inflation explains most of the variability of inflation. Next is the money supply from the 3rd quarter that explains nearly $20 \%$ of the variation of CPI, from the 6 th quarter explains over $35 \%$ of the variation of CPI; Exchange rate, export, and import from the 6th quarter explains over $10 \%$ of the variation of CPI (Table 8). It can be seen that the variability of output in the first quarter is almost entirely explained by its factors. Next is the export from the third quarter explains over $10 \%$, from the fourth quarter onwards explains nearly $20 \%$ of the variation of output. The import, from the 5 th quarter, explains nearly $10 \%$ of the variation in output. Exchange rates and CPI explain about $5 \%$ of the variation in output (Table 8). The results have shown that a small economy with a large openness like Vietnam, economic growth is heavily influenced by exports and imports.

\section{Table 8}

Variance decomposition of DLCPI

\begin{tabular}{|c|c|c|c|c|c|c|c|}
\hline Period & S.E. & DLCPI & DLGDP & DLER & DLM2 & DLX & DLIM \\
\hline 1 & 0.015336 & 100.0000 & 0.000000 & 0.000000 & 0.000000 & 0.000000 & 0.000000 \\
\hline 2 & 0.016165 & 92.43642 & 0.068311 & 0.036458 & 2.726758 & 3.623401 & 1.108652 \\
\hline 3 & 0.018253 & 72.52372 & 0.054355 & 1.556755 & 19.40470 & 5.408825 & 1.051648 \\
\hline 4 & 0.019022 & 68.03557 & 0.741114 & 1.661251 & 20.78135 & 5.013440 & 3.767270 \\
\hline 5 & 0.020208 & 62.43182 & 1.272452 & 2.375543 & 25.93031 & 4.591067 & 3.398804 \\
\hline 6 & 0.021960 & 53.05451 & 1.177424 & 2.627506 & 35.68218 & 4.095856 & 3.362523 \\
\hline 7 & 0.023156 & 47.90247 & 1.423879 & 3.699841 & 38.80299 & 3.911084 & 4.259733 \\
\hline 8 & 0.024451 & 43.33831 & 1.360917 & 4.999937 & 42.24871 & 3.880484 & 4.171642 \\
\hline 9 & 0.025881 & 38.93241 & 1.398227 & 5.947670 & 46.06459 & 3.552740 & 4.104369 \\
\hline 10 & 0.027229 & 35.40885 & 1.836640 & 7.178477 & 48.31581 & 3.243516 & 4.016703 \\
\hline
\end{tabular}


Table 8

Variance decomposition of DLGDP

\begin{tabular}{|c|c|c|c|c|c|c|c|}
\hline Period & S.E. & DLCPI & DLGDP & DLER & DLM2 & DLX & DLIM \\
\hline 1 & 0.015336 & 0.115067 & 99.88493 & 0.000000 & 0.000000 & 0.000000 & 0.000000 \\
\hline 2 & 0.016165 & 0.722515 & 94.74603 & 1.607032 & 0.715685 & 2.201506 & 0.007229 \\
\hline 3 & 0.018253 & 4.622035 & 77.30035 & 4.307843 & 0.600977 & 11.78094 & 1.387856 \\
\hline 4 & 0.019022 & 4.386590 & 70.06533 & 3.720098 & 2.037879 & 18.07505 & 1.715054 \\
\hline 5 & 0.020208 & 4.056842 & 64.80139 & 4.672527 & 1.921135 & 17.15899 & 7.389117 \\
\hline 6 & 0.021960 & 5.545313 & 61.49768 & 4.534813 & 1.909568 & 17.80709 & 8.705535 \\
\hline 7 & 0.023156 & 5.938456 & 60.01492 & 4.428085 & 3.109109 & 18.00730 & 8.502126 \\
\hline 8 & 0.024451 & 6.156734 & 58.22736 & 5.294884 & 3.043338 & 18.80663 & 8.471060 \\
\hline 9 & 0.025881 & 6.133168 & 57.46427 & 5.118048 & 3.278303 & 18.30588 & 9.700333 \\
\hline 10 & 0.027229 & 6.058719 & 56.94137 & 5.329885 & 3.761147 & 18.20936 & 9.699516 \\
\hline
\end{tabular}

\section{Some discussions and recommendations}

The article used the VAR model to assess the impact of exchange rate on inflation and economic growth in Vietnam. Quarterly data from the first quarter of 2005 to the third quarter of 2018 were used for the analysis. The granger test, reaction function, and variance decomposition have also shown certain effects from exchange rate to export, import, money supply, output, and prices in the economy. The research team gives some discussions based on the model results.

\section{- Test results have shown the unclear impact of exchange rates on output}

This can be understood because of the policy of keeping exchange rate with the little adjustment has been performed for a long time leading to the inertia of the economy. The stable exchange rate contributes to maintaining a stable macro environment, by contrast it creates a relying on others habit for the enterprises, they only airm on taking advantage of cheap labor and resources, not really pay attention in technology and added value for products in order to improve competitive advantages and productivity. Sometime, they are not interested in or have no measures to prevent exchange rate risks. The decision No. 2730/QD-NHNN issued by the State Bank of Vietnam on December 31, 2015 for announcement of the central exchange rate of Vietnam Dong against the US dollar, the cross rate of Vietnam Dong against some other foreign currencies show that Vietnam has transitioned to the regime floating exchange rate controlled by state. This is a necessary decision for exchange rates to be operated more flexibly, creating development for the forex market. In the context of international integration, with the characteristics of Vietnam's economy, which is small in scale but large in openness, does not depend heavily on a large partner, the flexible management of exchange rate and keeping exchange rate in accordance with a basket of currencies will help Vietnam avoid adverse shocks from world commodity and monetary markets, stabilize exchange rate and ensure policy flexibility.

\section{- The impact of exchange rate on inflation is quite clear}

When the exchange rate increases, the model results show that CPI rises immediately in the first quarter. In addition, the results of variance decomposition indicate that the persistence of past inflation explains most of the fluctuation in currency inflation, followed by supply money. The model results also show that when the exchange rate increases, the money supply increases initially and then almost does not fluctuate. It can be understood because the money supply is strictly controlled by the State Bank of Vietnam. From 2012 through 2018, the State Bank of Vietnam has been very flexible and successful in using valuable papers to intervene in order to stabilize exchange rates and money supply. Therefore, in order to maintain macroeconomic stability, the Government needs to ensure the active and flexible management of monetary and exchange rate policies in order to control inflation, stabilize macroeconomic, and stabilize the value of domestic currency, improve confidence and benefits of people and investors if they hold Vietnamese dong; In addition, it is necessary to continue developing the derivative instruments market to help prevent exchange rate risks.

\section{- A rising in the exchange rate in the first 3 quarters contributes to an increase in exports, but also growing imports}

This can be explained by the fact that Vietnam is a country with a high percentage of imported goods for the production of export goods, so the increase in exports will stimulate imports. Besides, variance decomposition also indicates that exports and imports explaine most of the variation in output in Vietnam is appropriate. This also shows that Vietnam's economy is very vulnerable due to too much reliance on exports while exports are not sustainable and rely on imported raw materials, so there is a need for stimulus to increase the localization rate and enhance the competitiveness of Vietnamese exports. The Government needs to innovate an export growth model based on the exploitation of competitive advantages to improve productivity, quality and export efficiency as follow:

(i) Reduce the rate of imported inputs within the value of exports. This is a measure to enhance the effect of exchange rate impacts on exports and is a direct factor affecting the improvement of the trade balance; 
(ii) Renovate the structure of export goods in the direction of increasing the proportion of high value-added commodities, boosting exports of goods using modern technology based on technological innovation;

(iii) For export markets, in addition to the main markets such as the US, EU, Japan, Korea, etc. it is necessary to actively penetrate new markets such as Africa, Central Asia, and South America, which may become a potential market need to exploit to increase export value;

(iv) State management agencies need to support enterprises to renovate production techniques, improve labor productivity to enhance competitiveness, and at the same time support in mechanisms and capital for enterprise;

(v) Actively implement activities to expand the product consumption market, especially with products that Vietnam has currently strong competitiveness such as agricultural products, seafood, textiles, wooden products, electronics to enhance trade promotion activities as organizing trade fairs, specialized exhibitions

(vi) Increase domestic and foreign market forecasting activities, timely disseminate market information, early detect and take measures to overcome technical barriers.

\section{Conclusion}

This article has implemented the VAR self-regression vector model to examine the impact of the exchange rate on the growth and inflation in Vietnam over the period 2005-2018. The results of the Granger test, reaction function, variance decomposition have shown that there are certain effects from exchange rate to export, import, money supply, output, and prices in the economy. The results have indicated that the persistence of past inflation explains most of the variation in current inflation; money supply volatility is the next variable that can explain the variability of inflation while the variation in output in the first quarter is almost entirely explained by the factor itself. Next, are export and import, they are important variables that can explain the variability of growth. A rising in the exchange rate not only contributes to an increase in export, but also helps growing import. From the results of the model, the research team has given some recommendations to contribute to improving Vietnam's business environment, ameliorating the trade balance, controlling inflation and supporting economic growth, realizing the goal of macroeconomic stability.

\section{Acknowledgement}

The authors would like to thank the anonymous referees for constructive comments on earlier version of this paper.

\section{References}

Bodart, V. (1996). Multiple exchange rates, fiscal deficits and inflation dynamics. IMF Country Report No. 06/422, Washington D.C.

Hung, L. V., \& Pfau, W. D. (2009). VAR analysis of the monetary transmission mechanism in Vietnam. Applied Econometrics and International Development, 9(1), 165-179.

Huyen, T. T. T. (2018). Exchange rate policy and macroeconomic stability in Vietnam. VNU Journal of Science: Economics and Business, 34(2), 1-16

International Monetary Fund (2006). Vietnam: Statistical Appendix. IMF Country Report No. 06/52

International Monetary Fund (2018). Vietnam: Statistical Appendix. IMF Country Report No. 18/207

Ito, T., \& Sato, K. (2008). Exchange rate changes and inflation in post-crisis Asian Economies: Vector Autoregression Analysis of the exchange rate pass-through. Journal of Money, Credit and Banking, 40(7), 1407-1438.

Nguyen, T. H. (2011). Relationship between the exchange rate and the international balance of payments - theory and practice in Vietnam. Ph.D. Thesis at Foreign Trade University, National Library of Vietnam

Lan, N.P. (2010). Monetary transmission mechanism from a quantitative analytical perspective. Banking Magazine, 18. https://www.sbv.gov.vn/webcenter/portal/vi/links/cm100?dDocName=CNTHWEBAP01162521905, Access date: 23 May, 2019

Nhung, N. C., \& Huyen, T. T. T. (2017). Exchange rate pass-through into Vietnamese import prices by industries and by countries. International Business Management, 11(11), 1834-1843.

Minh,V. V. (2009). Exchange rate pass-through and its implications for inflation in Vietnam. Vietnam Development Forum, Working Paper 0902.

Trang, L.T. (2017). Exchange rate policy boosts Vietnam's exports, Ph.D. Thesis at Trade University. National Library of Vietnam

Tung, H.T., \& Van Anh, N.T (2018). Discussion on the Impact of Money Policy to Growth and Inflation in Vietnam in the Period 2008 - 2017 from the Results of the VAR Model. Baasana International Conference 2018 in Vietnam, Baasana Vietnam Chapter, Foreign Trade University, Vol. 8, Issue. FTU -1.

Vo, T. T., Dinh, H. M., Do, X. T., Hoang, V. T., \& Phan, C. Q. (2000). Exchange rate arrangement in Vietnam: information content and policy options. Individual Research Project, East Asian Development Network (EADN). 


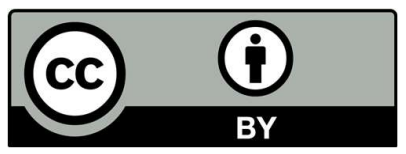

(C) 2020 by the authors; licensee Growing Science, Canada. This is an open access article distributed under the terms and conditions of the Creative Commons Attribution (CC-BY) license (http://creativecommons.org/licenses/by/4.0/). 